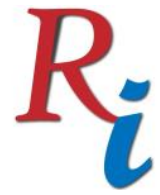

Asia Proceedings of Social Sciences

(APSS)

www.readersinsight.net/APSS

\title{
INCLUSIVENESS IN HIGHER EDUCATION LEADERSHIP: THE IMPACT OF STRAIGHTENING THE RELEVANCE OF MIDDLE- LEVEL MANAGEMENT IN LEADING UNIVERSITIES
}

\section{Muftahu Jibirin Salihu}

National Higher Education Research Institute (NaHERI)

Universiti Sains Malaysia

Malaysia

muftahu@usm.my

*Corrosponding author's Email: $\underline{\text { muftahu@usm.my }}$

Peer-review under responsibility of 4th Asia International Multidisciplinary Conference 2020 Scientific Committee http://connectingasia.org/scientific-committee/ (C) 2020 Published by Readers Insight Publisher, Office \# 6, First Floor, A \& K Plaza, Near D Watson, F-10 Markaz, Islamabad. Pakistan, editor@readersinsight.net This is an open access article under the CC BY-NC-ND license (http://creativecommons.org/licenses/by-nc-nd/4.0/). 


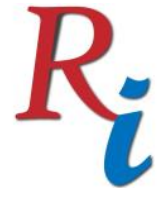

Asia Proceedings of Social Sciences

(APSS)

www.readersinsight.net/APSS

\section{A b s t r a c t}

The concept of inclusive leadership tends to be understood from different perspectives and contexts. However, there is a consensus that inclusive leadership has proven to be one of the effective leadership styles for ensuring sustainable development. Clearly, this is embedded in the leaders' ability to recognise bias, demonstrate an open mindset, and most importantly have the ability to acknowledge and empower others, especially those at sub-managerial level who are mostly in touch with the realities of policy implementation within an institution. While studies have proven the impactful role of middle-level management towards organisational performance, it was clear that the middle-level management at the universities are those set of leaders that are usually in full engagement with the university community including lecturers and students, thereby making them wholly responsible for the implementation of university policies at micro level. However, this class of leaders seems to be excluded or not fully recognised in deliberating and taking managerial decisions in the university leadership. Consequently, the intention of this paper is to critically conceptualised the six empirically acknowledged concepts of inclusive leaders and leadership framework by Bourke and Dillon which are courage, commitment, cognisance of bias, curiosity, cultural intelligence as well as collaboration and fully contextualised them in higher educational institutions with respect to straightening the relevance of middle-level management in leading universities.

Keyword: Inclusiveness, Higher Education, Leadership, Middle-Level Management

\section{Re se a r c h H i g h I i g h t s}

According to UNESCO (1998), higher education includes 'all types of studies, training, or training for research at the post-secondary level, provided by universities or other educational establishments that are approved as institutions of higher education by the competent state authorities'. Higher education is also available through certain college-level institutions including career colleges that award academic degrees or professional certifications. Tertiary education of non-degree level is sometimes referred to as 'further education' or 'continuing education' as distinct from higher education.

Leadership is all about vision, energy, engagement, direction, and alignment. This is what Parkin (2017) called VEEDA. Indeed, vision is developing with a group (the plan you have as a leader, you cannot execute them alone but with a group of assistants), and it is a shared vision of a better state, creating energy around that vision, (the vision cannot be attained without manpower - intellectual persons that can help achieve the vision) engaging people with that vision, (let them know about the future plans and be part of that plan) and then directing and aligning activities towards that vision. This is very much what leadership is about. 


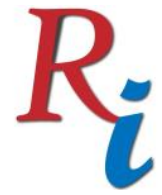

\section{Asia Proceedings of Social Sciences \\ (APSS) \\ www.readersinsight.net/APSS}

\section{IncIusive Leadership}

Leadership is about the present and the future. We need both. They may be captured in the same person or in different people. Leadership should be viewed as something shared or distributed through conversation and consent to acknowledge complexity in a complex environment facing complex challenges. However, Salihu (2019c) has decried the resistance of higher education leaders, especially university leaders, in response to these complex challenges. Thus, leadership should not be a lonely activity but rather an activity with others. The key aspects of sharing leadership are things flowing to the point of need, working with multiple partners, multiple stakeholders displaying their intellectual capacities, and coalescing services for the benefit of the institutions. If there is a failure to share or distribute leadership, there is a likelihood of not getting the desired result despite the expertise possessed by the staff in the educational institutions (Banks, 2008).

As one of the leadership components synthesised by Salihu (2019b), other aspects of good leadership are trust, delegation, involving others, and empowerment of individuals. Within the context of higher education, leadership is about having the ability to adapt to change. The higher the stakes of change, the more the leadership function and inspiration need to be present and evident. This is because in higher education or university context, success is multifaceted, owing to the fact that universities or higher educational institutions do many things such as research, learning and teaching, knowledge exchange, local community engagement, internationalisation, transnational education, and multidisciplinary research so success is across many fronts. It should be noted that in the university context, the politics could be quite complex the relationships could be interwoven, and power relationships could be quite hazy, and various leadership framework may exist to suit different context and situation (Salihu 2019a),. Thus, many leaders are leading through influence rather than traditional authority and influence requires relationships and trust. This is why higher education environment needs not a mere leadership but high-calibre leadership from people who are very self-aware, can speak the truth with their own voice, can be authentic but can also make difficult decisions in difficult circumstances (Bourke \& Dillon, 2016).

The middle-level academic management in universities are mostly heads of departments whose roles at the departmental level are clear and straightforward but when it comes to contact with that of the top-level leaders in the university, there are always blurring lines that deny clear demarcation or dichotomy of duties. It may sound fair to create rigid or clear dichotomy between their roles and that of others in universities but the circumstances surrounding the smooth running, confidentiality, and success of the university may not allow that to happen. Hence, the middle-level managers or leaders are the middle persons between those perching at the top of the ladder and those placed at the bottom. Without them and fairness to them, the chain of commands or directives will break or be misused. They are the winds needed for flying and forging ahead (Nguyen, 2012). 


\section{Research Objectives}

The objectives of the study are:

1. To explain the broader spectrum of middle-level leadership in the university and

2. To examine the impact of creating dichotomy in the relevance of middle-level leaders in inclusive leadership.

\section{Methodology}

This study employed a systematic literature review owing to the need to choose a suitable procedural technique in answering the research questions (Salihu, 2016). As indicated in the abstract, this study critically conceptualises the six empirically acknowledged concepts of inclusive leaders and leadership framework by Bourke and Dillon (2016) which are courage, commitment, cognisance of bias, curiosity, cultural intelligence as well as collaboration, and fully contextualised them in higher education.

\section{Results and Findings}

Findings from the analysis of the empirical studies and available data show that leadership in this century has taken a new dimension and the best way to lead is to work with others harmoniously. This is more important when the leaders at the top have developed good rapport with the middle-level leaders who serve as the tools to manage, direct, and use the entire body of staff. This is more particular in higher education where success of the institution cannot be limited to one aspect of the university's multifaceted activities. Therefore, the six traits of inclusive leadership as proposed by Bourke and Dillon (2016) are found suitable in ensuring inclusiveness in higher education leadership specifically universities.

The traits are as follows:

1. Commitment: An inclusive leader shows high commitment to diversity. This requires the right person at the right position ample time and mental energy to scrutinise. This applies to all stages of university leadership but it is certainly more appropriate to the top leaders including the Senate in giving consideration to the middle-level managers within the university leadership. Similarly, for leaders' commitment to meet success, they need to treat the team members with fairness, respect, and appreciation of their uniqueness, among others.

2. Courage: An inclusive leader has the personal determination to challenge the current state of affairs, colleagues, and even oneself with the hope of addressing any problem. Although this courageous approach is likely to be seen as a bottoms-up approach to inclusiveness which is assumed to be top-down, it becomes almost necessary with 


\section{Asia Proceedings of Social Sciences (APSS) \\ www.readersinsight.net/APSS}

leaders at the faculty and departmental levels because they are whom much is expected by the top leaders of the university and they too have colleagues and subordinates who they need to be fully engaged with in decisions which are usually communicated to the university's top management for further action. Thus, they need to summon enough courage to impeccably discharge their duties with justice and fairness with their superiors and subordinates respectively.

3. Cognisance of bias: Leaders as proponents of inclusion acknowledge their personal weaknesses and limitations and concurrently seek contribution from others so as to bridge the gap their limitations may create. Such leaders are more likely to admit their mistakes without holding someone as a scapegoat. This implies that the university's top management may stay in full authority or total control but simultaneously seek assistance from the middle-level university leaders on issues he or she is less confident in.

4. Curiosity: This refers to wanting to know the opinions of other colleagues on a particular issue. Heads of department in universities can be a reservoir of experiences so they may make well-informed decisions. Therefore, the university's top management are strongly encouraged to explore the knowledge and experience of these middle-level leaders so that they are more in touch with the realities at the grassroots level.

5. Cultural intelligence: Inclusive leaders are aware of the value of other cultures and they respect them and their adherents while simultaneously being fundamentally authentic. This is to be flexible and ready to adapt new ideas when they seem to bring the desired change. For example, this involves careful deliberation on issues such as structuring institutional buildings to be friendly to people with disabilities, setting academic calendar, and minding diverse cultural festivals, among other things.

6. Collaboration: The golden rule in inclusive leadership is to share and distribute. The attitude of certain universities' top management making laws without consultations with the middle-level management may result in a disaster as they may not even think of a problem which could have been pointed out by an included member who is responsible for the implementation laws.

\section{Conclusion}

Leadership in all organisations and higher education in particular is all about carrying everyone along as well as making them feel a sense of belonging and togetherness, which will help the leaders to share responsibilities and daunting tasks among them. This encourages everyone to contribute their best, brings unity and respect, and simultaneously save the leaders a lot of time and energy while maximising their successes and minimising failures. This is most needed when it comes to middle-level leaders in higher educational institutions who are mostly 


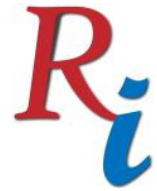

\section{Asia Proceedings of Social Sciences (APSS) \\ www.readersinsight.net/APSS}

responsible for delivering tasks as they struggle up and down to bridge the gap and create meaningful understanding and excellent achievements within the institution.

\section{REFERENCES}

Banks, S. P. (Ed.). (2008). Dissent and the failure of leadership (New horizon in leadership studies). Cheltenham: Edward Elgard.

Bourke, J., \& Dillon, B. (2016, April 14). The six signature traits of inclusive leadership: Thriving in the diverse new world. Deloitte Insights. Retrieved from https://www2.deloitte.com/us/en/insights/topics/talent/six-signature-traits-ofinclusive-leadership.html

Nguyen, T. L. H. (2012). Middle-level academic management: A case study on the roles of the heads of department at a Vietnamese university. Tertiary Education and Management, 19(1), 1-15. https://doi.org/10.1080/13583883.2012.724704

Parkin, D. (2017). Leading learning and and teaching in higher education: The key guide to designing and delivering courses. Oxford: Routledge.

Salihu, M J., (2019b). A Conceptual Analysis of the leadership Theories and Proposed Leadership Framework in Higher Education. Asian Journal of Education and Social Studies, 5(4): 1-6, 2019. pp 1-7. https://doi.org/10.9734/ajess/2019/v5i430164

Salihu, M. J. (2016). Qualitative and quantitative debates in contemporary educational research. International Journal of Research in Educational Methodology, 7(5), 1323-1327. https://doi.org/10.24297/ijrem.v7i5.4343

Salihu, M. J. (2019a). A conceptual analysis of the leadership theories and proposed leadership framework in higher education. Asian Journal of Education and Social Studies, 5(4), 1-6. https://doi.org/10.9734/ajess/2019/v5i430164

Salihu, M. J. (2019c). The challenges of knowledge age and transformational leadership in higher education institutions. International Journal of Research and Innovation in Social Science, 3(12), 405-409.

UNESCO. (1998). Higher education in the twenty-first century: Vision and action. World Conference on Higher Education. Paris: UNESCO. 